\title{
GATHERED UPON THE LANDSCAPE
}

\author{
Oscar Tantoco Serquiña, Jr. \\ University of the Philippines - Diliman \\ otserquina@up.edu.ph
}

\begin{abstract}
About the Author
Oscar Tantoco Serquiña, Jr. is assistant professor at the Department of Speech Communication and Theatre Arts of the University of the Philippines. He is currently a doctoral student in the School of Culture and Communication at the University of Melbourne. His works have appeared in Kritika Kultura, Humanities Diliman, the Philippine Political Science Journal, and Kasarinlan: Philippine Journal of Third World Studies, among others.
\end{abstract}




\section{The Fountain}

I

Dart of birds and stroke of wind

By La fontaine des Innocents,

Where water trickles

On basins of solid matter.

Hypnotic the sensorium

Of the plaza becomes,

Full of men and animals,

Each affirming each,

Splendid entities of the Earth

Becoming more than real

Under the sun's lambent light.

At the center of the square is the fountain,

Lifted on a pedestal of marble or stone,

Glorious in ancient age and intricate

In its statuaries of deities,

Creatures, nymphs. What does it become-

This sculptured monument in open air-

In happening gatherings

Of strangers at its feet? 
Derricks and crates, drills and cranes regulate the city's Modern arrangement. Their machineries bruise views To the sky's azure blue, to build the latest venue

For consumption-the biggest in Europe, the skeptic locals say-

Erasing a once sacred space now almost no longer there For touristic navigation. A new appetite swells From mechanisms of machines, and a former civilized order Disappears, never again to be seen, in the routines

Of trade. What is imperiled in what is being erected?

In the plaza square, where the length of silhouettes signifies loss

Of light, a woman has to find her way out

Of this maze, this disaster in the making.

But before leaving, she makes a wish, Her last coin now lodged deep into the mouth Of the water fountain. Still and supine, The day dutifully remains. 
III

Between this corner and that distance,

This lazy hour and the next, The little girl runs after doves

That fly and flutter and croon

In the city's busy plaza square.

And when she screams in glee

At the sight of sudden flight, her still-bright heart

Worn on her sleeve for everyone

To see, we know her still-young life

knows no grief it cannot contain.

She is not suffering, she is innocent, she is withheld from man's original sin.

She approaches the fountain full

To the brim, delighted by birds that bask

And bathe in cold liquid and sunlight,

Her reflection in the pool of water

An evidence of her presence

In her surrounding's well-managed decay.

A smile for what she witnesses-

Feathers everywhere, shadow 
On the ground, circular motion above her

Swift as today's path of sun.

Her joy too contagious

To be named, her face lifted

To the sky like a votive request.

When she points to a direction

Too common to be recognized

And says, "Maman, regardez!"

Her words are codes to what signify possession.

And we consider what have caught her attention-

How they glide and lift, soar and tilt

This side of morning-our eyes relearning

The lost beauty of symmetries.

Do we owe her an explanation

For the things she does not know?

For what may give, and be given up,

Once she learns, in old age,

What can arrive and leave?

There are no words. This is her relation

to the Earth that makes her alive. 
IV

When I tell you to meet me at a point in the city

Where a fountain lies at the center of a plaza square,

And I do not intend to extend my instructions further,

The way I start a letter and end it midway,

Without proper punctuations or final

Valedictions, it is my way of telling you I am lost.

You must not trust me. There are many fountains, of course,

And there, too, are countless cities in this corner of the Earth.

But you insist for an encounter-to meet eye to eye,

Face to face-even if the resident flock

Of birds has already gone tired and left.

The trust you give me is too much hurt to admit.

I come from miles away, and my origin is a continent

Like a fact you have never heard of

And do not bother to respond to.

This anonymity drives your desire to own

What cannot be yours.

I am unknown to you,

Other to the ordered terrain

You are accustomed to

And talk about with pride.

Treat me with caution,

Dear stranger. To you my color

May be a blanket of danger,

My language, a primitive hunger.

I have endured cruel weathers.

So when I tell you your kind

Is too much for the threshold

Of my heart, your grace excessive

For what I can take in,

I am telling you

Turn your back and leave.

Kritika Kultura 33/34 (2019/2020): 910-913

(C) Ateneo de Manila University

<http://journals.ateneo.edu/ojs/kk/> 


\section{Meditation}

I introduce you

to the stories

I have collected in years,

one uncovering

the other, each

confirming each.

I talk about the dearth

of pleasure, the permutation

of grief, the battered

woman who whispers

wilted flowers of my dreams.

Almost always I speak

in terms of excesses,

like the ominous stretch

of the walled city,

like the perennial habit

of build-and-collapse.

Today I show you topiaries,

the projection of steeples

toward the sky.

Somewhere, daylight

on the pavement,

on the unassuming face

of a child. I confide in you

what the skyline amasses

night and day. Then I point

to a direction and speak

of an expanse

of land, seeds, a shell

found nearby a dead

river. Which means

I am thinking about grace.

Which means I know 
about your yearning

for fields and fish-

palpable proofs

of what is not here.

So when I tell you

this place is yours,

as it is mine,

you must believe me.

We are gathered

in the Metro,

and you must learn

to say yes.

Kritika Kultura 33/34 (2019/2020): 912-913

(c) Ateneo de Manila University

<http://journals.ateneo.edu/ojs/kk/> 


\section{Passage}

There should be more time like this, to sit and dream.

It's as his cousin says:

Living-living takes you away from sitting.

-Louise Gluck, “Twilight”

Sunset came early that night, and the sky easily turned into an unusual pitch dark. I parted the curtains of my room, pushed open the large glass window leading to the landscape outside, drew a chair to sit on. It was slow and silent, this process of moving things around. Before me, a partial view of the suburbs of the city in which I study. I took hold of what I saw: houselights warming the horizon, tendrils and vines slithering through walls, a woman peeping through her window at the beck and call of the neighborhood's resident crow. I did not know what I wanted that August summer, countless miles away from home. I turned away, I left, I arrived. The view was a betrayal to the grime of the world that made me. It sustained me, gave me bliss, the scent of wonder that rose from its ground was hard to ignore. Offering itself like an invitation, it was to be had. In those minutes of calm, between the French skyline and myself, something had begun: a connection maybe, a deep reflection on what could be mine. I was a young man then, selfish and impressionable. I was too happy to know betrayal, too hungry to abandon abundance. All I wanted was to be free. Come in, the visible world seemed to whisper, and I entered. Who was I to say no? 